\title{
Effects of zeolite inclusion in aflatoxin B1-contaminated diet on the performance of laying duck
}

\author{
I. Sumantri, H. Herliani, A. N. Rajibi and R. Edriantina \\ Department of Animal Science, Faculty of Agriculture, University of Lambung Mangkurat, \\ Jl. Ahmad Yani KM 36, Banjarbaru, 70714 - Indonesia \\ *Corresponding E-mail: isumantri@ulm.ac.id
}

Received March 24, 2019; Accepted June 30, 2019

\begin{abstract}
ABSTRAK
Penelitian bertujuan mengetahui efektivitas penggunaan zeolit sebagai adsorben aflatoksin dalam pakan terkontaminasi aflatoksin B1 (AFB1) terhadap performans itik petelur. Penelitian menggunakan rancangan acak lengkap dengan perlakuan: (1) pakan komersial (Control); (2) pakan terkontaminasi AFB1 $70 \mathrm{ppb}$ (AFC); (3) Control $+2 \%$ zeolit; (4) AFC $+2 \%$ zeolit. Setiap perlakuan memiliki 4 ulangan dengan 4 ekor itik setiap ulangan. Penelitian menggunakan itik Alabio (Anas platyrinchos Borneo) betina berumur 8 bulan. Perlakuan pakan berlangsung selama 28 hari. Data dianalisis variansi menggunakan prosedur General Linear Model software SPSS 21.0. Hasil memperlihatkan paparan AFB1 70 pbb menyebabkan penurunan bobot badan sekitar $1,12 \%(P<0,05)$. Imbuhan zeolit dapat menghindari dampak paparan AFB1 terlihat dengan naiknya bobot badan sekitar 2,95\% pada pakan $\mathrm{AFC}+2 \%$ zeolit. Perlakuan tidak berpengaruh terhadap produksi telur dan bobot telur $(p>0,05)$. Paparan AFB1 menghasilkan bobot potong yang lebih rendah $(P<0,05)$, namun dengan imbuhan zeolit, itik yang menerima pakan terkontaminasi AFB1 menghasilkan bobot potong yang paling tinggi. Bobot relatif hati itik pada AFC sebesar 16,62\% turun menjadi 15,4\% dengan imbuhan zeolit. Disimpulkan bahwa imbuhan zeolit sebesar 2\% dapat mengurangi dampak paparan AFB1 terhadap kinerja itik petelur, khususnya penurunan bobot badan.
\end{abstract}

Kata kunci: Aflatoksin B1, itik petelur, kinerja produksi, zeolit

\section{ABSTRACT}

The research was objected to study the effect of zeolite inclusion in aflatoxin B1 (AFB1) contaminated diet on the performance of laying duck. A completely randomized design was adopted in the in vivo experiment that consisted of 4 treatments, namely: (1) commercial feed (Control); (2) AFB1contaminated feed $70 \mathrm{ppb}(\mathrm{AFC})$; (3) Control $+2 \%$ zeolite; and (4) AFC $+2 \%$ zeolite. Each treatment had 4 replications with 4 ducks in each replication. A total of 64 eight months-female Alabio duck (Anas platyrinchos Borneo) were used in 28 days of the feeding experiment. Data were analyzed according to the general linear model of SPSS 21.0 statistical software. Results indicated that AFB1 exposure significantly $(\mathrm{P}<0.05)$ decreased the body weight of laying duck by $1.12 \%$. Zeolite inclusion could prevent the adverse effect of AFB1 on body weight that increased by $2.95 \%$ in AFC $+2 \%$ zeolite. Treatments had no significant effect on egg production and egg weight $(\mathrm{P}>0.05)$. Zeolite inclusion resulted in the highest final body weight whilst AFB1 diet without zeolite resulted in the lowest final body weight $(\mathrm{P}<0.05)$. Relative liver weight of duck fed_AFC diet was $16.62 \%$ and to be $15.4 \%$ by zeolite addition in the diet. In conclusion, $2 \%$ of zeolite inclusion could reduce the adverse effects of AFB1 exposure on the performance of laying duck.

Keywords:Aflatoxin B1, laying duck, performance, zeolite 


\section{INTRODUCTION}

Aflatoxin B1 (AFB1) is highly carcinogenic and genotoxic compounds produced by fungi, especially toxigenic species of Aspergillus flavus and $A$. parasiticus. The consumption of feed containing AFB1 by the animal can result in excretion of a hydroxylated metabolite of aflatoxin, namely aflatoxin M1 (AFM1), in the animal products, such as milk, meat, and eggs (Voelkel et al., 2011; van der Fels-Klerx and Camenzuli, 2016). In order to avoid AFB1 exposure on livestock and ingestion of its residues by consumers, the Indonesian government has established the maximum limit of AFB1 contamination in feed for the industry. However, tropical climate causes high occurrences and levels of AFB1 contamination in feed for ruminant and poultry in Indonesia (Agus et al., 2013; Sumantri et al., 2017).

Several strategies have been developed to minimize the toxic effects of aflatoxins on animal and the transfer of its residues into animal products, such as physical, chemical, and biological methods. However, in recent years the use of aflatoxin adsorbent is the most frequently studied method because it is considered as an effective, safe, economical and applicable method (Kutz et al., 2009). One of the aflatoxin adsorbents is zeolite, a tectosilicates mineral that has the ability to bind aflatoxin so that it can prevent the absorption of AFB1 in the digestive tract of livestock (Li et al ., 2010). Zeolites have a microporous structure that forming a large internal surface. This is associated with their high cation exchange capacity $(\mathrm{Ca} 2+)$ that makes zeolites efficiently adsorbing polar molecules such as AFB1 (Di Gregorio et al., 2014).

Many studies have been conducted to determine the efficacy of processed clays, including zeolite, in response to aflatoxin challenge to dairy cow, broiler and meat duck (Sulzberger et al., 2017; Fowler et al., 2015; Mallek et al., 2012; Chang et al., 2016). However, little information on the use of natural zeolite dealing with laying duck fed AFB1-contaminated diet has been found. Duck is highly sensitive to aflatoxin exposure because of differences in hepatic and extra-hepatic enzymes responsible for AFB1 metabolism (Diaz and Murcia, 2011). Consumption of AFB1 contaminated diet will not only adversely affect on duck's performance but may result in residues in the products (Zhang et al., 2016). Therefore, this research was aimed to investigate the ameliorate effects of natural zeolite inclusion in AFB1 contaminated diet on the performance and health of laying duck.

\section{MATERIALS AND METHODS}

\section{Experimental Diet}

AFB1-contaminated diet (AFC) was produced as follow: commercial feed for laying duck (IP333, PT. Wonokoyo) was used as a medium. The medium was added with aquadest to reach $30 \%$ of moisture content. The medium was inoculated with $A$. flavus FNCC 612 then it was incubated in temperature $35^{\circ} \mathrm{C}$ for 10 days. The concentration of AFB1 in the medium was analyzed by ELISA test to calculate the dilution factor of the medium in the experimental diet. Indonesian National Standard of Industry (SNI) has established the threshold level of AFB1 in complete commercial feed that was $20 \mathrm{ppb}$ (Kementan RI, 2009). Previous studies showed the detrimental effects of AFB1 on the performance of duck was observed in the level of $50 \mathrm{ppb}$ or more (Ostrowski-Meisnerr, 1983; Sumantri et al., 2017). Therefore, this experiment was applied the level of contamination at $70 \mathrm{ppb}$. The medium then were mixed with commercial feed based on the dilution factor to obtain AFB1 levels of AFC at $70 \mathrm{ppb}$.

The zeolite used in the experiment was a natural zeolite which is mined and purchased in Central Java (PT. Brataco Chemika). Zeolite was ground using a mortar and sieved through 100 mesh. Experimental diet composition is presented in Table 1.

\section{In Vivo Experiment}

Eight months, sixty-four female Alabio ducks (Anas platyrinchos Borneo) were used in the experiment. Ducks were weighed and randomly assigned to 4 dietary treatments with 4 replicates of 4 ducks in each experimental unit. The mean of the duck's body weight when randomized into dietary treatment was $1,247 \pm 145$ g. The treatments were: commercial feed as a control diet (P1); AFB1 - contaminated diet 70 ppb (P2); Control $+2 \%$ zeolite (P3); and AFC + 2\% zeolite (P4).

Dietary treatment was given_when the egg production, Duck Day Average (DDA) reached $70 \%$. The experiment was carried out for 4 weeks. The experimental diet was provided twice a day and restricted, about $150 \mathrm{~g} / \mathrm{bird} / \mathrm{day}$, to ensure the level of AFB1 exposure on the animal was 
Table 1. Composition of Experimental Diets

\begin{tabular}{lrrrr}
\hline \multicolumn{1}{c}{ Ingredients } & $\begin{array}{c}\text { Control diet } \\
(\mathrm{P} 1)\end{array}$ & $\begin{array}{c}\mathrm{AFC} * * \\
(\mathrm{P} 2)\end{array}$ & $\begin{array}{c}\mathrm{P} 1+2 \% \text { zeolite } \\
(\mathrm{P} 3)\end{array}$ & $\begin{array}{c}\text { P2+2\% zeolite } \\
(\mathrm{P} 4)\end{array}$ \\
\hline Commercial complete feed (\%)* & 100 & 90 & 100 & 90 \\
AFB1-production medium (\%) & 0 & 10 & 0 & 10 \\
Natural zeolite (\%) & 0 & 0 & 2 & 2 \\
Analysis & & & & \\
Dry matter (\%) & 88 & 88 & 88 & 88 \\
Crude protein (\%) & 18 & 18 & 18 & 18 \\
Crude fat (\%) & 7 & 7 & 7 & 7 \\
Crude fiber (\%) & 6 & 6 & 6 & 6 \\
Ash (\%) & 14 & 14 & 14 & 3.3 \\
Calcium (\%) & 3.3 & 3.3 & 3.3 & 0.8 \\
Phosphorous & 0.8 & 0.8 & 0.8 & 2800 \\
Metabolizable energy (kkal/kg) & 2800 & 2800 & 2800 & 70 \\
Aflatoxin B1 (ppb) & 0 & 70 & 0 & \\
\hline
\end{tabular}

*The commercial complete feed for laying duck is IP333 produced by PT. Wonokoyo Tbk.

$* * \mathrm{AFC}=$ Aflatoxin $\mathrm{B} 1$ contaminated diet

controlled. Water was provided ad libitum.

Egg production was recorded and weighed daily, starting at 15 th day until the 28th day of treatment. Body weight of duck was measured individually at two weeks before treatment (D14), the beginning of treatment (D0), the second week of treatment (D14), and the fourth week of treatment (D28). At the end of the experiment (D28), ducks were slaughtered, then carcass and giblet were collected and weighed. The observed variables were body weight changes, egg production (egg weight and DDA), the percentages of carcass, liver, and intestine weights, and histopathology of the liver.

Liver histopathology was diagnosed as follow: representative liver samples were fixed in $10 \%$ buffered neutral formalin. Sections were cut at 5-micron thickness and stained by the hematoxylin and eosin method of Harris (Bancroft and Gamble, 2008).

\section{Data Analysis}

Feed samples were analysed for AFB1 concentrations by ELISA method using ELISA kit AgraQuant ${ }^{\circledR}$ ELISA Aflatoxin B1 (Romer Labs, Singapore). Data of body weight, egg weight, DDA percentage, carcass percentage, liver percentage, and intestine weight were analysed by the general linear model procedure using the IBM SPSS 21.0 statistical program. Significant differences between treatment means were separated using Duncan's multiple range test with a $5 \%$ probability.

\section{RESULTS AND DISCUSSIONS}

\section{Body Weight}

Treatments had a significant effect on live weight changes $(\mathrm{P}<0.05)$. Table 2 shows that AFB1 exposure at $70 \mathrm{ppb}$ caused a decrease in duck weight, as seen in AFC treatment, which experienced an average weight loss of $-0.87 \%$ after four weeks of treatment. This adverse effect of AFB1 exposure on body weight could be reduced by zeolite inclusion in the diet. This was indicated by the average of live weight of ducks in $\mathrm{AFC}+2 \%$ zeolite diet that increased by $3.20 \%$. Zeolite also significantly improved duck performance, as seen in control diet $+2 \%$ zeolite, that had the highest body weight gain $(4.86 \%)$. This gain was higher than the control ducks (P1) which only increased by $2.57 \%$.

The adverse effects of AFB1 on growth performance was_related with a decrease in the 
efficiency of protein and energy utilization due to the deterioration of the digestive system of the birds (Denly et al., 2009). Recent studies in broilers suggested that absorptive surface of small intestine would deteriorate during chronic exposure to low levels of AFB1, thus declines absorption of nutrient in the intestine (GalarzaSeeber et al., 2016). Figure 1 clearly shows that the presence of AFB1 in the diet (P2) decreased the growth performance of the duck.

Study on the effects of AFB1 on the performance of laying ducks is still limited. In 1st-day-old ducklings which received a feed containing AFB1 at levels up to $100 \mathrm{ppb}$ for 21 days showed that an increase in AFB1 level caused a decrease in weight gain (Wan et al., 2013). Research on chickens showed a decrease in broiler body weight fed $200 \mathrm{ppb}$ AFB1 for 8 weeks, from $1,999 \mathrm{~g}$ to $1,853 \mathrm{~g}$ (Mani et al., 2001). Yunus et al. (2011) concluded that in chickens, consumption of aflatoxin caused weight loss, decreased feed consumption, and increased feed conversion. The percentage of weight loss reported varies depending on the dose and duration of exposure, such as $5 \%$ weight loss at a dose of $500 \mathrm{ppb} ; 10 \%$ weight loss at a dose of 800

Table 2. Effects of Treatment Diets on Live Weight Change of Laying Ducks

\begin{tabular}{lcccc}
\hline \multirow{2}{*}{ Treatment Diets } & Initial Weight (g) & Final Weight_(g) & \multicolumn{2}{c}{ Body weight Change } \\
\cline { 4 - 5 } & & & Gram & $\%$ \\
\hline Control diet (P1)* & $1,382 \pm 139$ & $1,411 \pm 110$ & $29.06 \pm 102^{\mathrm{ab}}$ & $2.57 \pm 7.8^{\mathrm{ab}}$ \\
AFC (P2)** & $1,447 \pm 94$ & $1,431 \pm 92$ & $-16.25 \pm 101^{\mathrm{a}}$ & $-0.87 \pm 7.4^{\mathrm{a}}$ \\
$\mathrm{P} 1+2 \%$ zeolite (P3) & $1,405 \pm 139$ & $1,469 \pm 134$ & $64.06 \pm 99^{\mathrm{b}}$ & $4.86 \pm 7.3^{\mathrm{b}}$ \\
$\mathrm{P} 2+2 \%$ zeolite (P4) & $1,386 \pm 142$ & $1,427 \pm 130$ & $40.94 \pm 66^{\mathrm{ab}}$ & $3.20 \pm 5.5^{\mathrm{ab}}$ \\
\hline
\end{tabular}

*Control diet is a commercial complete feed for laying duck (IP333 PT. Wonokoyo Tbk.)

**AFC is a diet containing AFB1 at the level of $70 \mathrm{ppb}$

$\mathrm{a}, \mathrm{b}$ means in the same column with different superscripts differ significantly $(\mathrm{P}<0.05)$

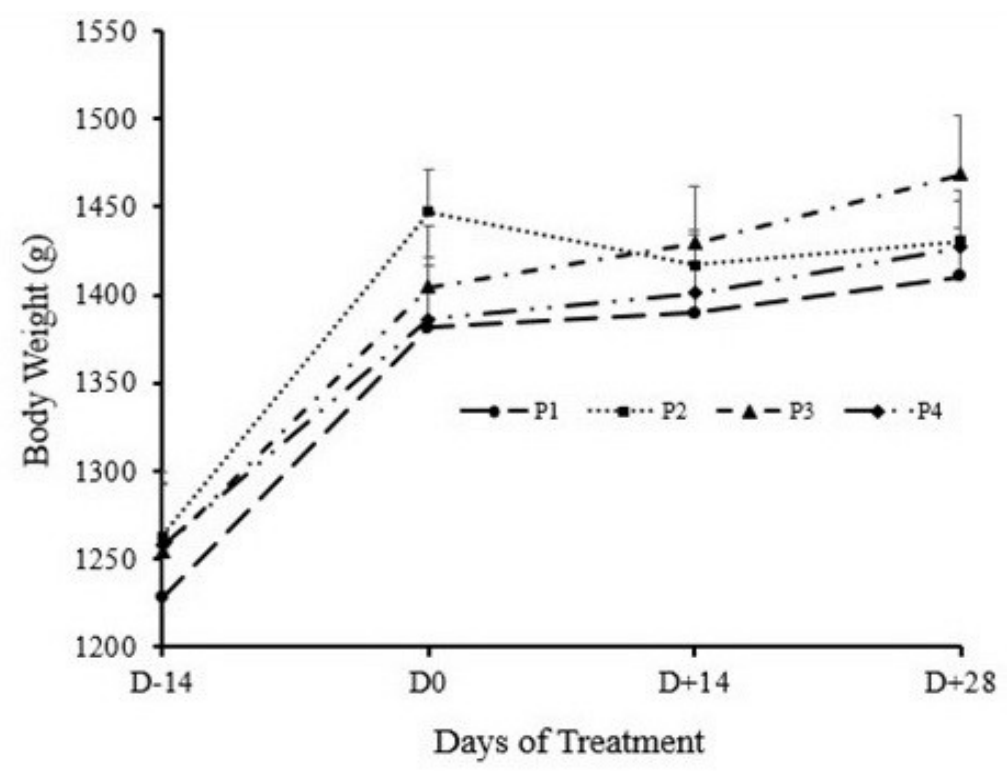

Figure 1. Live Weight Curves of Laying Ducks Treated with Control Diet (P1); AFB1-contaminated Diet $70 \mathrm{ppb}(\mathrm{P} 2) ; \mathrm{P} 1+2 \%$ zeolite (P3); and $\mathrm{P} 2+2 \%$ zeolite (P4) 
ppb for 28 days; and $15 \%$ weight loss at a dose of $1,000 \mathrm{ppb}$ for 21 days (Yunus et al., 2011).

This study indicated the positive effect of zeolite inclusion in the diet for laying duck. The addition of $2 \%$ zeolite in the control diet (P3) resulted in the highest final live weight. By zeolite inclusion, the growth performance of duck receiving AFB1 contaminated diet (P4) was still higher than those of the control ducks. This finding suggested that the use of zeolite can reduce the impact of exposure to AFB1 on body weight. Chemically, zeolite is a clay group of aluminosilicate minerals which has a threedimensional structure consisting of skeletons of $\mathrm{SiO}_{4}$ and $\mathrm{AlO}_{4}$ which form interconnected channels wherein the channel cavity there are weak bonds of $\mathrm{H}_{2} \mathrm{O}$ molecules and alkali cations $(\mathrm{Na}, \mathrm{K}, \mathrm{Li}, \mathrm{Ca}, \mathrm{Mg}, \mathrm{Ba}, \mathrm{Sr}$ ) which offset the charge negative from $\mathrm{AlO}_{4}$ (Mallek et al., 2012).

In ducklings, the use of $0.1 \%$ clay adsorbent can reduce the negative impact of AFB1 exposure (Wan et al., 2013). In broiler, the dietary use of natural or synthetic zeolites has been reported to improve feed efficiency, thus resulting in better growth performance of broilers (Mallek et al., 2012). Zeolites (montmorillonites) are a class of the smectite clay group, which has 3-layer structures that allow adsorbing heavy metals, bacteria, and toxic antinutritive agents (Fowler et al., 2015; Sulzberger et al., 2017). The binding between aflatoxin and the adsorbent forms an inert and stable complex, so it will prevent the absorption of aflatoxin in the gastrointestinal tract (Huwig et al., 2001).

\section{Egg Production}

In this study, the treatments had no effect on egg production and egg weight $(\mathrm{P}>0.05)$.
However, as shown in Table 3, AFB1 contamination in the diet tended_to reduce egg weight, and the addition of $2 \%$ zeolite tended to increase egg weight despite the presence of AFB1 contamination in the feed ( $p=0.433)$.

Aflatoxin-contaminated feed causes a decrease in egg production, as shown in the study of Exarhos and Gentry (1982), namely egg production fell from $85 \%$ to $40 \%$ in laying eggs given AFB1 1,000 ppb for 6 weeks. At lower doses, the study of Aly and Awer (2009) showed that the production and egg weight of white leghorn laying hens were not affected by feed contaminated with aflatoxin at the levels of 100 ppb for 60 days, although feeding with aflatoxin contamination caused a decrease in feed consumption. Research of Zaghini et al. (2005) showed a decrease in egg weight of laying hens receiving AFB1 2,500 ppb for 4 weeks, this was due to a decrease in the percentage of eggshell weight and thinner eggshells due to the AFB1 exposure through contaminated feed consumption. Evidences suggest that AFB1 causes induction or inhibition of liver mixedfunction-oxygenase activities that affect the metabolism of exogenous and endogenous substrates in the liver.

\section{Weights of Carcass, Liver, and Intestine}

This experiment showed that the treatments have a significant effect $(\mathrm{P}<0.05)$ on final body weight. Nevertheless, the treatments did not have significant effects on carcass percentage, the relative weight of giblet, and relative weight of the liver (Table 4 and Table 5).

Duck carcass meat is mostly located in breast and thigh, therefore the weights of breast and thigh muscles are the main factor of carcass

Table 3. Effects of Treatment Diets on Egg Production of Laying Ducks

\begin{tabular}{llcc}
\hline \multicolumn{1}{c}{ Treatment Diets } & DDA (\%) & Egg Production $(\mathrm{g})$ & Egg Weight $(\mathrm{g})$ \\
\hline Control diet (P1)* & $54.40 \pm 3.7$ & $4,147 \pm 217$ & $70.70 \pm 3.7$ \\
AFC (P2)** & $64.58 \pm 9.2$ & $4,842 \pm 736$ & $69.23 \pm 3.4$ \\
P1+2\% zeolite (P3) & $56.71 \pm 8.4$ & $4,417 \pm 590$ & $72.10 \pm 1.5$ \\
P2+2\% zeolite (P4) & $58.56 \pm 12.6$ & $4,488 \pm 886$ & $70.81 \pm 1.1$ \\
\hline
\end{tabular}

Means in the same column indicate are not significantly different Control diet is a commercial complete feed for laying duck (IP333 PT. Wonokoyo Tbk.)

**AFC is a diet containing AFB1 at the level of $70 \mathrm{ppb}^{*}$ 
Table 4. Effects of Treatment Diets on Final Body Weight, Carcass Weight, Giblet Weight, Liver Weight, and Small Intestinum Weight of Laying Ducks

\begin{tabular}{lcccc}
\hline Treatment Diets & $\begin{array}{c}\text { Final Body Weight } \\
(\mathrm{g})\end{array}$ & $\begin{array}{c}\text { Carcass Weight } \\
(\mathrm{g})\end{array}$ & $\begin{array}{c}\text { Giblet Weight } \\
(\mathrm{g})\end{array}$ & $\begin{array}{c}\text { Liver Weight } \\
(\mathrm{g})\end{array}$ \\
\hline Control diet (P1)* & $1,460 \pm 110^{\mathrm{ab}}$ & $833 \pm 29$ & $352 \pm 123$ & $43.8 \pm 8.4$ \\
AFC (P2)** & $1,426 \pm 55^{\mathrm{a}}$ & $847 \pm 128$ & $289 \pm 105$ & $47.5 \pm 15.9$ \\
P1+2\% zeolite (P3) & $1,406 \pm 90^{\mathrm{a}}$ & $835 \pm 121$ & $300 \pm 80$ & $43.0 \pm 9.6$ \\
P2+2\% zeolite (P4) & $1,576 \pm 104^{\mathrm{b}}$ & $951 \pm 76$ & $324 \pm 33$ & $49.5 \pm 5.1$ \\
\hline a, b Means in the same column with different superscripts differ significantly (P<0.05) \\
* Control diet is a commercial complete feed for laying duck (IP333 PT. Wonokoyo Tbk.) \\
**AFC is a diet containing AFB1 at the level of 70 ppb
\end{tabular}

Table 5. Effects of Treatment Diets on the Percentages of Carcass, Giblet, and Liver of Laying Ducks

\begin{tabular}{lccc}
\hline \multicolumn{1}{c}{ Treatment Diets } & Carcass (\%) & Giblet (\%) & Liver (\%) \\
\hline Control diet (P1)* & $57 \pm 5.0$ & $42 \pm 15.6$ & $14 \pm 4.8$ \\
AFC (P2)** & $59 \pm 7.3$ & $36 \pm 15.9$ & $17 \pm 1.3$ \\
P1+2\% zeolite (P3) & $59 \pm 5.5$ & $37 \pm 13.2$ & $15 \pm 2.2$ \\
P2+2\% zeolite (P4) & $60 \pm 1.5$ & $34 \pm 3.2$ & $15 \pm 1.9$ \\
\hline
\end{tabular}

*Control diet is a commercial complete feed for laying duck (IP333 PT. Wonokoyo Tbk.)

**AFC is a diet containing AFB1 at the level of $70 \mathrm{ppb}$

yield in_duck. Study of Chang et al. (2016) showed that_diet containing aflatoxin at $62-65 \mathrm{ppb}$ significantly reduced_live weight, breast muscle weight, and thigh muscle weight of meat male ducks at various age.

Although the statistical test did not show any difference in the relative weight of all variables, it was seen that in AFB1 contaminated diet groups (P2 and P4) was found an enlargement of the liver, with a relative weight of $16.62 \%$ and $15.40 \%$, which was heavier than the control $(13.54 \%)$. These results were also found in the relative weights of the intestines for P2 and P4 groups, namely $16.93 \%$ and $18.2 \%$ respectively, which were heavier than the controls (14.19\%).

This study applied a relatively low of AFB1 contamination level in the diet, but this is a common level of AFB1 contamination that found in feed and feedstuffs for a duck in Indonesia according to Sumantri et al. (2017). At a low dose of aflatoxin exposure, the performance of birds were relatively similar, but the_changes in liver size and pathology can be detected (Magnoli et al., 2011). Denli et al. (2009) found broiler liver enlargement after receiving feed containing AFB1 at $1,000 \mathrm{ppb}$.

Liver is the target organ of AFB1 because most of the AFB1 absorbed will undergo bioactivation to form a compound 8.9-epoxide which then binds to protein and DNA (Pasha et al., 2007). Our study indicated mild acute degeneration of vacuoles in the liver of ducks received control diet, but this degeneration was severe in P2 diet. In zeolite groups, mild vacuoles degeneration was found in $\mathrm{P} 3$ ducks and medium degeneration was in P4 ducks (Figure 2).

Hepatic lesions correlated with aflatoxicosis is described as vacuolation of hepatic cells due to fatty metamorphosis. This metamorphosis is classified as degenerative changes of the liver (Espada et al., 1992). Study of Leenadevi et al. (1995) revealed that ducks are a very sensitive 


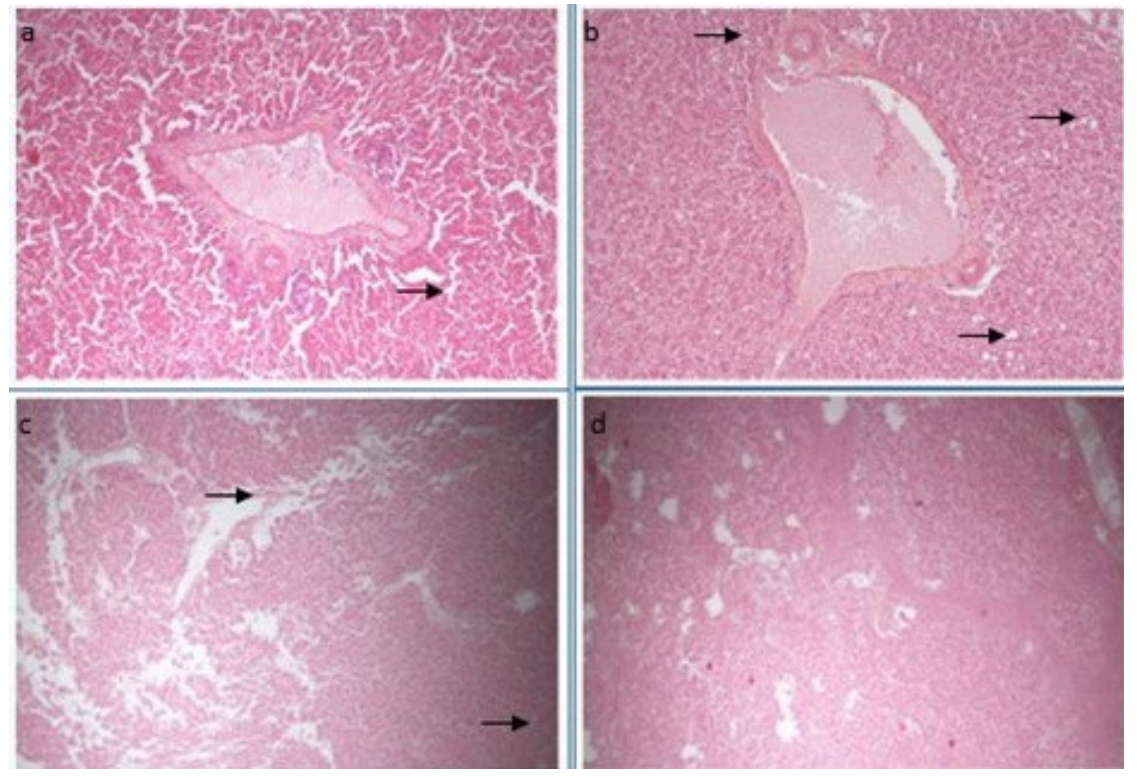

Figure 2. Acute Degenerative Hepatocyte in Liver Samples: a. Mild (P1: control diet); b. Severe (P2: P1 containing AFB1 $70 \mathrm{ppb}$ ); c. Mild (P3: P1 + 2\% zeolite); d. Medium (P4: P2 + 2\% zeolite).

species for aflatoxin injury and it would appear that they are also prone to develop hepatic tumours. The time taken for the tumour induction was about 90 days after oral exposure of AFB1 and histopathologically, they were categorized as hepatocellular carcinoma, cholangiocellular carcinoma, and chronic hepatitis.

Adsorbent inclusion in the diet has a protective effect against aflatoxin exposure. This experiment showed that zeolite inclusion seems to reduce the adverse effects of AFB1 exposure as indicated in the result of liver histopathology study of P3 and P4 groups. Similarly, Magnolli et al. (2011) found that in low levels of AFB1 (50 to $100 \mathrm{ppb}$ ), all livers samples of broilers showed histopathological alterations, with an accumulation of fat vacuoles, except the normal appearance of livers from broiler received bentonite in the diet.

\section{CONCLUSION}

Zeolite inclusions in AFB1-contaminated diet for laying ducks could reduce the adverse effects of AFB1 exposure, especially on body weight and liver histopathology, however it did not appear to increase the egg production.

\section{ACKNOWLEDGEMENT}

The authors would like to thank the
Directorate General of Research and Community Services KEMENRISTEKDIKTI for funding this research activity through the Higher Education Applied Research Scheme with contract No. 119/UN8.2/PL/2017.

\section{REFERENCES}

Agus, A., I. Sumantri, T.W. Murti and J. Boehm. 2013. Survey on the occurrence of aflatoxin B1 contamination in dairy ration and its carry over into the milk in Yogyakarta and Central Java Provinces of Indonesia. Book of Abstract, International Society of Mycotoxin and MycoRed International Conference "Europe 2013". Global Mycotoxin Reduction Strategies, CNR ISPA-International Society of Mycotoxin, Apulia, Italy, May 27-31, 2013. P. 223.

Aly, S.A. and W. Anwer. 2009. Effect of naturally contaminated feed with aflatoxins on performance of laying hens and the carryover of aflatoxin B residues in table eggs. Pakistan Journal of Nutrition 8 (2):181-186.

Bancroft, J. D. and M. Gamble. 2008. Theory and Practice of Histological Techniques. 6th Edition. Churchill Livingstone Elsevier. Philadelphia.

Chang, W., Q. Xie, A. Zheng, S. Zhang, Z. Chen, J. Wang, G. Liu and H. Cai. 2016. Effects 
of aflatoxins on growth performance and skeletal muscle of Cherry Valley meat male ducks. Animal Nutrition 2(3):186-191

Denli, M., J.C. Blandon, M.E. Guynot, S. Salado, and J.F. Perez. 2009. Effects of dietary AflaDetox on performance, serum biochemistry, histopathological changes, and aflatoxin residues in broilers exposed to aflatoxin B1. Poult. Sci. 88(7):14441451.

Diaz, G.J. and H.W. Murcia. 2011. Biotransformation of aflatoxin B1 and its relationship with the differential toxicological response to aflatoxin in commercial poultry species. In: AflatoxinsBiochemistry and Molecular Biology. (R.G. Guevara-Gonzalez, ed. In Tech Publishing. Rijeka. P. 3-20.

Di Gregorio, M.C., D.V. de Neeff, A.V. Jager, C.H. Corassin, Á.C. de Pinho-Carão, R. de Albuquerque, A.C. de Azevedo and C.A.F. Oliveira. 2014. Mineral adsorbents for prevention of mycotoxins in animal feeds. Toxin Rev. 33(3):125-135.

Espada, Y., M. Domingo, J. Gomez and M.A. Calvo. 1992. Pathological lesions following an experimental intoxication with aflatoxin B1 in broiler chickens. Res. Vet. Sci. 53(3):275-279.

Exarchos, C.C. and R.E. Gentry. 1982. Effect of aflatoxin on egg production. Avian Dis. 26(1):191-195.

Fowler, J., W. Li and C. Bailey. 2015. Effects of a calcium bentonite clay in diets containing aflatoxin when measuring liver residues of aflatoxin b1 in starter broiler chicks. Toxins 7(9):3455-3464.

Galarza-Seeber, R., J.D. Latorre, L.R. Bielke, V.A. Kuttappan, A.D. Wolfenden, X. Hernandez-Velasco, R. Merino-Guzman, J.L. Vicente, A. Donoghue, D. Cross, B.M. Hargis and G. Tellez. 2016. Leaky gut and mycotoxins: aflatoxin B1 does not increase gut permeability in broiler chickens. Front. Vet. Sci. 3:10.

Huwig, A., S. Freimund, O. Kappeli and H. Dutler. 2001. Mycotoxin detoxication of animal feed by different adsorbents. Toxicol. Lett. 122(2):179-188.

Kementerian Pertanian RI. 2009. Peraturan Menteri Pertanian Nomor 19/Permentan/Ot.140/4/2009 Tentang Syarat dan Tatacara Pendaftaran Pakan. Berita Negara Republik Indonesia Tahun
2009 Nomor 93. Jakarta.

Kutz, R.E., J.D. Sampson, L.B. Pompeu, D.R. Ledoux, J.N. Spain, M. Vazquez-Anon and G.E. Rottinghaus. 2009. Efficacy of Solis, NovasilPlus, and MTB-100 to reduce aflatoxin M1 levels in milk of early to mid lactation cows fed aflatoxin B1. J. Dairy Sci. 92(8):3959-3963.

Leenadevi, T., K.V. Valsala and A. Rajan. 1995. Aflatoxin induced hepatocarcinogenesis in ducks. Mycotoxin Res. 11(1):2-8.

Li, J., D. Suo and X. Su. 2010. Binding capacity for aflatoxin B1 by different adsorbents. Agric. Sci. in China 9(3):449-456.

Magnoli, A.P., M.P. Monge, R.D. Miazzo, L.R. Cavaglieri, C.E. Magnoli, C.I. Merkis, A.L. Cristofolini, A.M. Dalcero and S.M. Chiacchiera. 2011. Effect of low levels of aflatoxin B1 on performance, biochemical parameters, and aflatoxin B1 in broiler liver tissues in the presence of monensin and sodium bentonite. Poult. Sci. 90(1):48-58.

Mallek, Z., I. Fendri, L. Khannous, A. BenHassena, A. Traore, M.A. Ayadi and R. Gdoura. 2012. Effect of zeolite (clinoptilolite) as feed additive in Tunisian broilers on the total flora, meat texture and the production of omega 3 polyunsaturated fatty acid. Lipids in Health and Disease 11:35.

Mani, K., K. Sundaresan, and K. Viswanathan. 2001. Effect of immunomodulators on the performance of broilers in aflatoxicosis. Indian. Vet. J. 78(12):1126-1129.

Ostrowski-Meissner, H.T. 1983. Effect of contamination of diets with aflatoxins on growing ducks and chickens. Trop. Anim. Health Prod. 15(3):161-68.

Pasha, T.N., M.U. Farooq, F.M. Khattak, M.A. Jabbar, and A.D. Khan. 2007. Effectiveness of sodium bentonite and two commercial products as aflatoxin absorbents in diets for broiler chickens. Anim. Feed Sci. Technol. 132(1-2):103-110.

Sulzberger, S.A., S. Melnichenko and F.C. Cardoso. 2017. Effects of clay after an aflatoxin challenge on aflatoxin clearance, milk production, and metabolism of Holstein cows. J. Dairy Sci. 100(3):18561869.

Sumantri, I., A. Agus, B. Irawan, Habibah, N. Faizah and K. J. Wulandari. 2017. Cemaran aflatoksin dalam pakan dan produk itik alabio (Anas platyrinchos Borneo) di 
Kalimantan Selatan. Buletin Peternakan 41(2):163-168.

Sumantri, I., A. Agus, B. Irawan and Herliani. 2017. Effects of aflatoxin levels in the diet on aflatoxins residues in the liver, meat, and egg of laying duck. In the Proceeding of the 6th International Conference on Sustainable Animal Agriculture for Developing Countries. Faculty of Animal Husbandry Brawijaya University, Malang, Indonesia, October 16-19, 2017. P. 172.

Van der Fels-Klerx, H.J. and L. Camenzuli. 2016. Effects of milk yield, feed composition, and feed contamination with aflatoxin B1 on the aflatoxin M1 concentration in dairy cows' milk investigated using Monte Carlo simulation modelling. Toxins. 8(10):2-11.

Voelkel, I., E. Schroer-Merker and C.P. Czerny. 2011. The carry-over of mycotoxins in products of animal origin with special regards to its implications for the European Food Safety Legislation. Food Nutr. Sci.

\section{2:852-867.}

Wan, X.L., Z.B. Yang, W.R. Yang, S.Z. Jiang, G.G. Zhang, S.L. Johnston and F. Chi. 2013. Toxicity of increasing aflatoxin B1 concentrations from contaminated corn with or without clay adsorbent supplementation in ducklings. Poult. Sci. 92(5):1244-1253.

Yunus, A.W., E. Razzazi-Fazeli and J. Bohm. 2011. Aflatoxin B1 in affecting broiler's performance, immunity, and gastrointestinal tract: a review of history and contemporary issues. Toxins. 3(6):566590.

Zaghini, A.G., G. Martelli, P. Roncada, M. Simiolli and L. Rizzi. 2005. Mannanoligosaccharides and aflatoxin B1 in feed for laying hens: effects on egg quality, aflatoxins B1 and M1 residues in eggs, and aflatoxin B1levels in liver. Poult. Sci. 84(6):825-832. 